\section{Involving the public in research}

\author{
I. Needleman ${ }^{1}$
}

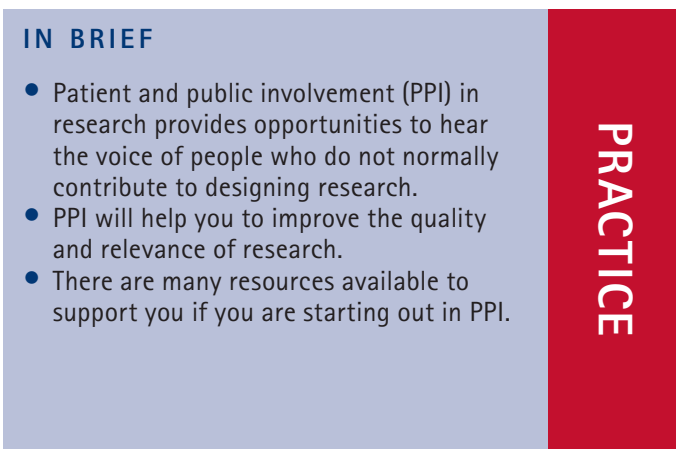

\begin{abstract}
Patient and public involvement (PPI) in research is a rapidly developing initiative across biomedicine. It recognises that in addition to being the subjects of research, patients, the public and other users have an important contribution to make to the development, quality and relevance of research and to be advocates for oral health research. These aspects are under increasing scrutiny in view of the financial squeeze on public funding and the ethical obligation of the research team to carry out the highest quality activity. This paper is an introduction to involving people in research and provides basic guidance on how to get started.
\end{abstract}

\section{INTRODUCTION}

As clinicians we aim to maintain or improve the health and wellbeing of individuals and communities worldwide. ${ }^{1}$ Over many decades, a wealth of scientific literature has made major contributions to achieving this aim. However, healthcare and research agendas are changing internationally. One of the main drivers of change is the recognition that most health research has been conducted on patients but very little has been conducted with patients. In other words patients or the public more widely have traditionally been used as research subjects but have rarely been asked to contribute to its development. This seems a curious state in the twenty-first century since the research has generally been designed to benefit the public. As a call to action, the UK National Institute for Health Research (NIHR) has recently stated '...you can't have high quality research without the involvement of the pub$\mathrm{lic}^{2}$ and has set out a five-year plan to encourage greater participation. ${ }^{3}$ Some areas, such as mental health, do appear to have stronger evidence for patients and public. ${ }^{4}$

In recognition of this increasing call to involve people in research, the aims of this paper are to introduce the concepts of patient and public involvement (PPI) in research and to discuss why this might be valuable, what types of collaboration can work, who should

'Unit of Periodontology, UCL Eastman Dental Institute, 256 Gray's Inn Road, London, WC1X 8LD

Correspondence to: Professor lan Needleman

Email: i.needleman@ucl.ac.uk

\section{Refereed Paper}

Accepted 8 August 2014

DOI: 10.1038/sj.bdj.2014.906

${ }^{\circledR}$ British Dental Journal 2014; 217: 421-424

\begin{tabular}{|c|c|}
\hline \multicolumn{2}{|c|}{ Examples of areas where PPI can be integrated into research - How can we improve the research? } \\
\hline Research question & $\begin{array}{l}\text { Is this an important question to investigate? } \\
\text { What are your priorities for research? } \\
\text { Who are the right people to carry out the research on? }\end{array}$ \\
\hline Study recruitment & $\begin{array}{l}\text { What do you think about the way we plan to recruit people to the study? } \\
\text { What do you think about the study information sheets? }\end{array}$ \\
\hline Treatment and outcomes & $\begin{array}{l}\text { What do you think about the way we plan to provide treatment within } \\
\text { the study? } \\
\text { What do you think about the way we plan to measure health and outcomes } \\
\text { of any treatment? }\end{array}$ \\
\hline $\begin{array}{l}\text { Analysing, interpreting } \\
\text { and sharing results }\end{array}$ & $\begin{array}{l}\text { What do you think about the way we plan to analyse the data? } \\
\text { What do you think about our interpretation of the data? } \\
\text { What do think about the way we have presented the results? } \\
\text { What do you think about the ways we plan to disseminate the findings }\end{array}$ \\
\hline
\end{tabular}

be involved and what resources are available to support PPI. It is important to note at this stage that public involvement in healthcare is at an early stage in development. There are few hard guidelines about what should or should not be done. Furthermore, it is important to state upfront that there is little evidence that PPI in research has improved health outcomes. Therefore, this article will not be prescriptive but will explore the potential of PPI in research. As more PPI is carried out, both the benefits and limitations will become clearer.

\section{WHAT IS PPI IN RESEARCH?}

Patient and public involvement (PPI) in research is about ensuring that the voice of patients, the public and other users, for example clinicians, contributes to the research not just as subjects on which research is carried out. In fact, PPI is also part of a wider agenda, that of public engagement.
Public engagement describes the myriad ways in which the activity and benefits of higher education and research can be shared with the public. Engagement is by definition a two-way process, involving interaction and listening, with the goal of generating mutual benefit.

The key concept of public engagement is two-way involvement between parties, each learning and gaining from the dialogue. The engagement might explore for instance people's priorities, preferences, concerns, how they do certain tasks/procedures, what issues they see as helping them to act or limiting their ability to do so etc. Debate and discussion can help to develop strategies that draw in and empower all parties or simply help to identify what is achievable. Outside of biomedicine, such an approach is common and might include a consultation on a controversial research area such as developing genetically modified crops. The 
consultation process allows 'expert' groups to inform people about the topic and to engage in discussion arising from the information. People are encouraged to share their views and perspectives and this might provide an opportunity to put forward specific questions about the research. Depending on the design of the engagement, the interaction dynamics may be complex including lay people learning from experts, experts learning from lay people and lay people learning from each other. Clearly, the potential for gaining insight, understanding and generating ideas for research is substantial.

\section{WHY INVOLVE THE PUBLIC IN RESEARCH?}

The chief reasons for involving the public are: to strengthen the voice of the public in research; to improve the quality and credibility of research; and the requirement to involve the public in research by ethics committees and funding organisations.

Strengthening the voice of patients and the public in research is partly an issue of democratic principles but also recognition that the public have an important contribution to make in research.

'No matter how complicated the research, or how brilliant the researcher, patients and the public always offer unique, invaluable insights. Their advice when designing, implementing and evaluating research invariably makes studies more effective, more credible and often more cost efficient as well.' Professor Dame Sally Davies, Chief Medical Officer ${ }^{6}$

Although there has been very little PPI in periodontal research, indications that patients have an important voice and perspective for research have been emerging in recent years. In particular, a number of studies have reported on the patient experience of living with periodontitis and the effect of treatment on this impact. What is emerging is an understanding that periodontitis can have profound effects on how people live their lives. Qualitative studies, where detailed interviews allow people to relate their own stories, have been particularly powerful in capturing the effect of periodontitis on self-esteem, ability to socialise, self-blaming, embarrassment and feelings of shame of having the condition, but have also provided positive insights including a recognition by people of the need to move on from the initial diagnosis and for partnering with the dental team for successful treatment. ${ }^{7,8}$ In relation to measuring effects of treatment, a recent trial investigating periodontal plastic surgery to treat gingival recession for aesthetic reasons showed clear differences between aesthetic success outcomes judged by the patients and by specialist periodontists. ${ }^{9}$ Although these studies

\begin{tabular}{|c|c|}
\hline Organisation & Resources \\
\hline $\begin{array}{l}\text { The Citizen Scientist } \\
\text { www.citizenscientist.org.uk/about-research/ }\end{array}$ & Resource for members of the public on health research \\
\hline $\begin{array}{l}\text { Cochrane Consumer Network } \\
\text { http://consumers.cochrane.org }\end{array}$ & $\begin{array}{l}\text { Cochrane Collaboration network that aims to increase } \\
\text { consumer involvement in systematic reviews. While } \\
\text { directed toward Cochrane Reviews, many aspects are } \\
\text { useful in other research }\end{array}$ \\
\hline $\begin{array}{l}\text { Folk.Us } \\
\text { www.folkus.org.uk }\end{array}$ & $\begin{array}{l}\text { Organisation that supports patients and the public to } \\
\text { undertake their own health research }\end{array}$ \\
\hline $\begin{array}{l}\text { Healthwatch England } \\
\text { www.healthwatch.co.uk }\end{array}$ & $\begin{array}{l}\text { Consumer champion for England with statutory } \\
\text { powers to strengthen the voice of consumers }\end{array}$ \\
\hline $\begin{array}{l}\text { INVOLVE } \\
\text { www.invo.org.uk }\end{array}$ & $\begin{array}{l}\text { Huge resource for PPI including library of evidence } \\
\text { about PPI and many toolkit/guidance documents }\end{array}$ \\
\hline $\begin{array}{l}\text { Involving People } \\
\text { www.wales.nhs.uk/sites3/home.cfm?orgid=1023 }\end{array}$ & Support for PPI in Wales \\
\hline $\begin{array}{l}\text { Involving People in Research } \\
\text { www.involvingpeopleinresearch.org }\end{array}$ & $\begin{array}{l}\text { Excellent resource from University of Western } \\
\text { Australia to support patients and researchers }\end{array}$ \\
\hline $\begin{array}{l}\text { James Lind Alliance } \\
\text { www.lindalliance.org }\end{array}$ & $\begin{array}{l}\text { Guidance on public engagement for priority setting } \\
\text { about uncertainties in clinical care }\end{array}$ \\
\hline $\begin{array}{l}\text { National Coordinating Centre for } \\
\text { Public Engagement } \\
\text { www.publicengagement.ac.uk }\end{array}$ & $\begin{array}{l}\text { Excellent resources and guidance on public } \\
\text { engagement. Established to support universities } \\
\text { but with freely available information. }\end{array}$ \\
\hline $\begin{array}{l}\text { National Institute for Health Research } \\
\text { www.ccf.nihr.ac.uk/PPI }\end{array}$ & Route map for designing PPI \\
\hline $\begin{array}{l}\text { NHS Involvement } \\
\text { http://nhsinvolvement.co.uk }\end{array}$ & $\begin{array}{l}\text { Website to provide opportunities for greater involve- } \\
\text { ment of the public in healthcare decision-making }\end{array}$ \\
\hline $\begin{array}{l}\text { National Voices } \\
\text { www.nationalvoices.org.uk }\end{array}$ & $\begin{array}{l}\text { Coalition of health and social care charities to } \\
\text { strengthen the voice of patients, public and charities }\end{array}$ \\
\hline $\begin{array}{l}\text { Patients Association } \\
\text { www.patients-association.org.uk } \\
\text { Scottish Patients Association } \\
\text { www.scotlandpatients.com/ } \\
\text { Patient and Client Council (Northern Ireland) } \\
\text { www.patientclientcouncil.hscni.net/ }\end{array}$ & $\begin{array}{l}\text { Organisations that support the public with information } \\
\text { and campaign for improvements in healthcare }\end{array}$ \\
\hline $\begin{array}{l}\text { People In Research } \\
\text { www.peopleinresearch.org }\end{array}$ & $\begin{array}{l}\text { Listings of opportunities for members of the public } \\
\text { to get involved in research } \\
\text { Database for researchers to add opportunities for } \\
\text { members of the public to get involved in research }\end{array}$ \\
\hline $\begin{array}{l}\text { Research design Service - National Institute } \\
\text { for Health Research } \\
\text { www.rds.nihr.ac.uk/ } \\
\text { patient-and-public-involvement/ }\end{array}$ & $\begin{array}{l}\text { Support for developing PPI in NIHR grant applications } \\
\text { through regional centres }\end{array}$ \\
\hline $\begin{array}{l}\text { Shaping our Lives } \\
\text { www.shapingourlives.org.uk }\end{array}$ & $\begin{array}{l}\text { Network aiming to achieve greater user involvement } \\
\text { in organisations }\end{array}$ \\
\hline $\begin{array}{l}\text { Wellcome Trust } \\
\text { www.wellcome.ac.uk/Funding/Public-engagement/ } \\
\text { index.htm }\end{array}$ & Funding for public engagement projects \\
\hline
\end{tabular}

have used the public as research subjects, it is not difficult to recognise the potential contribution that patients can make to improve the research itself from their expertise of what it is like to live with the condition and the experience of treatment. Such a contribution might help to identify for instance relevant outcomes of care, priorities for research development and how to share research findings more effectively with the public.

In terms of improvements in quality and credibility arising from PPI in research, the research base is growing and aspects that have benefited from public engagement include improved recruitment rates in clinical studies, clearer and more comprehensible patient information, securing funding for research, designing research protocols and selecting relevant outcomes. ${ }^{10,11}$ Researchers consistently report that they consider their research as benefiting from such an approach. ${ }^{5}$ Balancing this, the most common challenges identified for PPI in research are the additional time and funding that are required and an overarching worry of tokenistic engagement. ${ }^{6,11}$

In the UK, research ethics committees use patient involvement in the research development as a part of their assessment, expecting that it would normally be employed. Furthermore, many public funding 


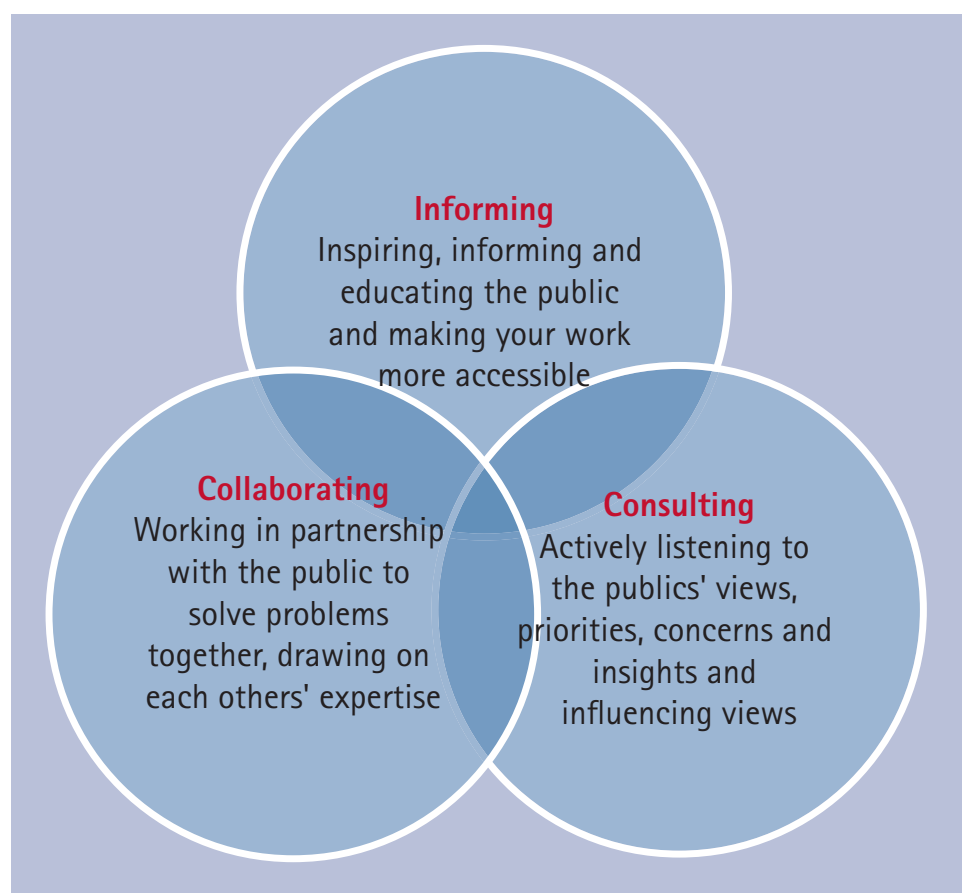

Fig. 1 Thinking about the purpose of your PPI in research. There are often overlaps between aims (modified from National Coordinating Centre For Public Engagement ${ }^{12}$ )

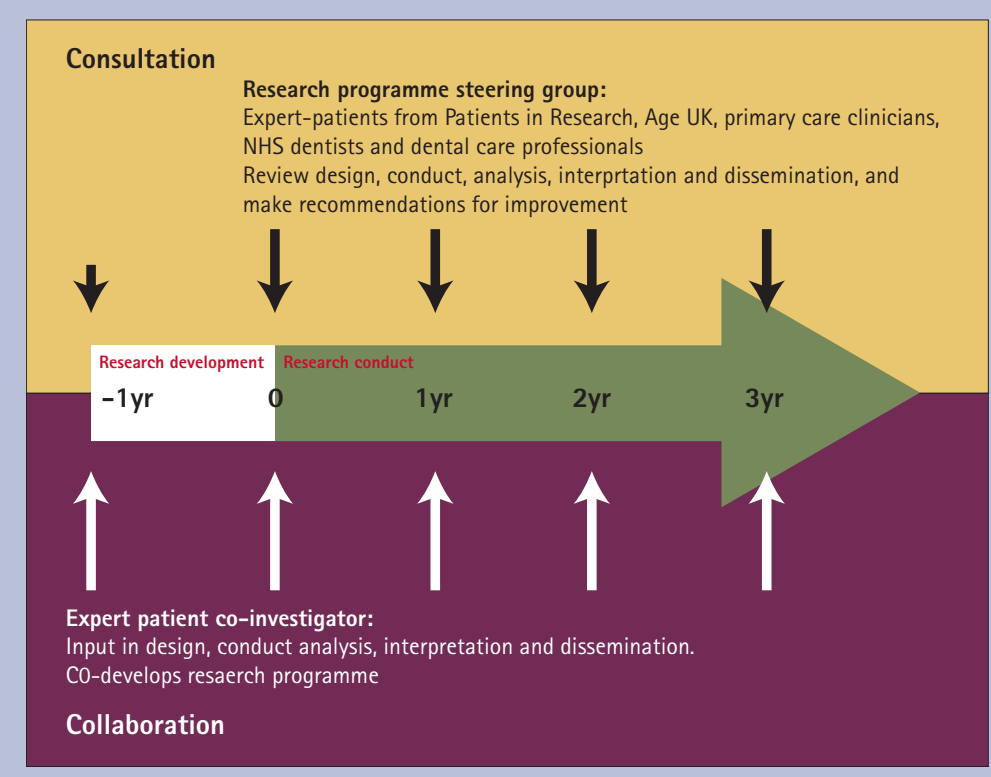

Fig. 2 PPI model (modified from National Institute for Health Research)

organisations such as the National Institute for Health Research, Medical Research Council and the Wellcome Foundation require information about PPI as part of the application process. The same is true for many medical charities.

\section{WHO SHOULD WE ENGAGE WITH?}

'Publics' is sometimes used as a term to cover all groups outside of the initial research team that might have an interest in the study. Patients with the condition of interest might be the most obvious group to include. Undoubtedly, this target group for healthcare is highly important and is the most frequently included group in public engagement in medicine. However, depending on the topic, other groups might also have an important voice that should be heard including the following:

- People at risk of developing the condition. For instance, in relation to periodontal diseases, any member of the public could develop the condition and have an important contribution to research, especially that aimed at health promotion and disease prevention. Certain groups also have an increased risk of developing periodontitis including those with diabetes and people who use tobacco

- Carers who look after others with the condition for instance family members, residential or in-patient carers

- Clinicians who provide primary care, for example dentists and dental care professionals
- Specialist clinicians who provide secondary/tertiary care

- Organisations representing clinical professionals for instance the British Society of Periodontology

- Organisations representing patients and vulnerable groups for instance the Patients Association and Age UK

- Organisations that fund or organise care or public health for example, National Institute for Health Research, Department of Health, Public Health England, BUPA Dental Care

- Allied healthcare settings and resources such as pharmacies, GP practices or supermarkets where people may seek advice or purchase supplies.

\section{FINDING AND RECRUITING PEOPLE TO INVOLVE IN RESEARCH}

Once the type of people to engage with has been decided, the next step will be to contact and recruit them. We have been surprised how enthusiastic people are to help once contacted. Depending on who you plan to involve, the following might be relevant to finding people:

- Dental or medical practices through personal approach, poster and leaflets

- Community health organisations

- Social media

- Patient advocacy and involvement groups (Table 2) for example, People in Research

- Dental hospitals and schools

- Local or national newspapers.

The people you ask will often be a valuable source of advice on how to reach others. Useful guidance and toolkits are also published by INVOLVE. Before approaching people, you should consider the following:

- How can I explain the project clearly to potential participants?

- What am I expecting from people participating (a brief 'job description')

- What can they expect from me? What support and training do they need; should I provide remuneration for out of pocket expenses and/or a gift/fee?

\section{WHERE CAN PPI INTEGRATE INTO ORAL HEALTH RESEARCH?}

Most healthcare research is conceived, designed, conducted, analysed, interpreted, reported and disseminated solely by academic researchers although with expertise in many different areas. PPI can help to improve the quality and relevance of these elements by incorporating a wider view of the topic area, for instance the values, preferences and experiences of patients and clinicians who normally receive/provide the care. Table 1 describes examples of areas that might be included in PPI. 


\section{TYPES OF PPI}

There are many different approaches to involving publics in research. The main consideration is to be clear about the purpose of the PPI (Fig. 1).

Along with establishing the aim of the PPI, deciding which groups of people to engage with will help to guide towards possible methods for the PPI. For instance, we have used a modified involvement model from the UK National Institute for Health Research (NIHR) to provide guide and structure (Fig. 2).

We used the above model for consultation relating to a study in the planning stage investigating the effect of periodontal therapy. In particular, the PPI was mapped mainly to the questions outlined in Table 1. We used three focus groups: Group 1. Patients treated for periodontitis; Group 2. Primary care dentists 3; Group 3. Mixed group of patients treated for periodontitis, dentists and hygienists. Each session commenced by setting ground rules and developed a sense of encouraging participation and respecting differences in views. A brief summary of the research problem and the proposed methods were described followed by a structured discussion that was led by an experienced facilitator. Key themes that emerged from the focus groups were:

- The proposed research questions were considered important health issues

- The development of a care-pathway was strongly supported although for different reasons: the patients felt that a carepathway would provide a better picture of treatment and likely outcomes to them whereas dentists emphasised the potential for standardisation of care and the use of the pathway for patient information

- A recommendation to include additional stakeholders in the advisory group

- The need to explore the relationship between initial expectations of treatment and actual outcomes achieved

- Dentists were less comfortable with care being influenced by research using quality of life measures than patients

- Patients suggested many additional approaches for sharing/disseminating study results that we had not considered.

Overall, what was initially surprising was that the mixed focus group (patient and dental care professionals together) facilitated rather than limited discussion and creativity. There was shared learning during the session with ideas developing out of the discussion. Furthermore, focus group members reported that their appetite for engaging in research was boosted by participating in the session. In terms of recruiting people to the focus groups, we found that patients and dental professionals were enthusiastic to participate although agreeing a time that was mutually convenient was challenging for the mixed groups.

\section{EVALUATION}

Evaluating the PPI activity is an important element of learning from the project. Clearly, achieving the set aims of the PPI will form one element for evaluation. However, it is also helpful to consider the activity more broadly. ${ }^{13}$

\section{The process of involvement}

Were you able to recruit the types of publics that you planned, were these appropriate to the research, did they have sufficient support during the involvement, were they clear about the purpose of the group and what was expected from them, did everyone contribute to the activity, did everyone feel they made a contribution to the activity?

\section{The impact of involvement}

What will you do differently as a result of the PPI, how have you and the other participants in the PPI changed as a result of the activity, was the activity well designed to achieve its stated aims, what types of experience and expertise have made a useful impact on the activity?

There is a variety of methods to evaluate these issues. In addition to the summary of the results of the PPI activity, a report could also describe the characteristics of who contributed and how much. A brief pre- and post-activity questionnaire to participants can be informative and this could be in a variety of formats including a traditional Word-type document, an online survey or telephone interview depending on the depth of what you want to evaluate. Evaluation is a core part of the PPI but does not need to burdensome to be useful. If fact, if it is easy to complete, it is more likely to be carried out and to yield useful learning.

\section{RESOURCES}

There is a wealth of resources available to support PPI activity; key resources and organisations are listed in Table 2. In addition, many university health faculties now include expertise to support and guide PPI and this is likely to be the best initial starting point. If you are applying for a National Institute for Health Research grant, their research design service, organised into regional centres, may also be able to assist in the design of PPI. In terms of developing a level of knowledge about PPI, the INVOLVE website is a useful starting point as it contains a huge amount of information, guidance and evidence (Table 2).
In conclusion, health-related research is changing rapidly to embrace the voice of the public and other users in its design and conduct. There is already a wealth of guidance and support to help researchers develop their skills in PPI. PPI has the potential to improve the quality and relevance of research and is a hugely enjoyable and enthusing activity. Furthermore, engagement with people who do not normally have a voice in research including patients, the public and primary care dental professionals may help to grow communities that will independently advocate for research to improve oral health. Within oral health research, PPI is at an early stage in development and there are many straightforward elements of PPI that researchers can incorporate into their research strategies without incurring significant financial cost. Oral health researchers are also well placed to contribute to the development of PPI within biomedicine more broadly.

1. Watt R G, Petersen P E. Periodontal health through public health - the case for oral health promotion. Periodontology 2000 2012; 60: 147-155.

2. National Institute for Health Research. Get involved. 2014a. Available at: http://www.nihr.ac.uk/awareness/Pages/default.aspx (acccessed 28 May 2014)

3. National Institute for Health Research. Promoting a Research Active Nation. 2014: http://www.nihr. ac.uk/documents/get-involved/Promoting\%20 A\%20Research\%20Active\%20Nation_NIHR\%20 Strategic\%20Plan_May\%202014.pdf (accessed 10 October 2014).

4. Ennis L, Wykes T. Impact of patient involvement in mental health research; longitudinal study. $\mathrm{Br} J$ Psychiatry 2013; 203: 381-386.

5. National Coordinating Centre for Public Engagement. Available at: www.publicengagement. ac.uk/what (acccessed 28 May 2014).

6. Staley K. Exploring impact: public involvement in NHS, public health and social care research. Eastleigh: INVOLVE, 2009.

7. Stenman J, Hallberg U, Wennström J L, Abrahamsson K H. Patients' attitudes towards oral health and experiences of periodontal treatment: a qualitative interview study. Oral Health Prev Dent 2009; 7: 393-401.

8. Karlsson E, Lymer U B, Hakeberg M. Periodontitis from the patients' perspective, a qualitative study. Int J Dent Hyg 2009; 7: 23-30.

9. Zucchelli $G$, Mounssif I, Mazzotti $C$ et al. Coronally advanced flap with and without connective tissue graft for the treatment of multiple gingival recessions: a comparative short-and long-term controlled randomized clinical trial. J Clin Periodonto/ 2014; 41: 396-403.

10. Nilsen E S, Myrhaug H T, Johansen M, Oliver $\mathrm{S}$, Oxman A D. Methods of consumer involvement in developing healthcare policy and research, clinical practice guidelines and patient information material. Cochrane Database Syst Rev 2006; CD004563.

11. Domecq J P, Prutsky G, Elraiyah T et al. Patient engagement in research: a systematic review. BMC Health Serv Res 2014; 14: 89.

12. National Coordinating Centre for Public Engagement. Why engage? Deciding the purpose of your engagement. Available at: www.publicengagement.ac.uk/what/purposes-of-engagement (accessed 28 May 2014)

13. UK Clinical Research Collaboration. An evaluation of the process and impact of patient and public involvement in the advisory groups of the UK Clinical Research Collaboration. 2009. Available at: www.ukcrc.org/wp-content/uploads/2014/03/PPI Evaluation_Report_es.pdf (accessed 12 September 2014) 